\title{
Characterization and Classification of Soils on an Agricultural landscape in Dingyadi District, Sokoto State, Nigeria
}

\author{
${ }^{* 1}$ M.B. Sharu, ${ }^{2}$ M. Yakubu, ${ }^{3}$ S.S. Noma and ${ }^{4}$ A.I.Tsafe \\ ${ }^{1}$ Department of Agricultural Science, Shehu Shagari College of Education, Sokoto \\ ${ }^{2}$ Faculty of Agriculture, Ibrahim Badamasi Babangida University, Lapai, Niger State, Nigeria \\ 3Department of Soil Science and Agricultural Engineering, Usmanu Danfodiyo University, Sokoto, Nigeria \\ 4Department of Pure and Applied Chemistry, Usmanu Danfodiyo University, Sokoto, Nigeria \\ [Corresponding Author, E-mail: mbsharu12@gmail.com; 留: +2348185066077]
}

\begin{abstract}
A semi-detailed fixed grid soil survey of Dingyadi District was conducted in order to obtain comprehensive soil data for characterization and classification. Three soil mapping units TLL1, TUP2 and TUP3 were identified on the basis of land forms and surface texture. Morphological properties of the soil reveal that soil unit TLL1 is deep, imperfectly drained and generally loamy sand in texture. TUP2 was well drained with deep rooting zone and texture varies from loamy sand on the surface to sandy clay loam in the subsoil. Soil unit TUP3 has an impermeable layer at less than $50 \mathrm{~cm}$ depth with generally gravelly sand texture. Physical properties of the soils indicate a relative high bulk density and low porosity. Mean equilibrium infiltration rates (MEIR) $\left(\mathrm{cmhr}^{-1}\right)$ for soil units TLL1, TUP2 and TUP3 were 20, 40 and 32 respectively. The dominant exchangeable bases were calcium and magnesium with the soils having high base saturation. The soils were neutral to slightly alkaline in reaction. Organic matter, available $\mathrm{P}$, total $\mathrm{N}$ and CEC contents of the soils were generally low. According to USDA Soil Taxonomy System, soil units TLL1, TUP 2, and TUP 3 were classified as Typic Endoaqualfs, Typic Haplustepts and Lithic Ustorthents, respectively and correlate with Haplic Luvisols, Argic Lixisols and Ruptic Cambisols in WRB system of Classification.

Keywords: Characterization, Classification, Agricultural Landscape, Mapping units, and Morphological Properties.
\end{abstract}

\section{INTRODUCTION}

There is an increasing demand for information on soils as a means to produce food (Fasina et al 2007). Agriculture is the predominant economic activity in Nigeria and because of agricultural development and increasing demand for experimental data in Nigeria, much work is carried out on soil characterization. This provides the basic information necessary to create functional soil classification schemes, and assess soil fertility in order to unravel some unique soil problems in an ecosystem (Lekwa et al., 2004). The coupling of soil characterization, soil classification and soil mapping provides a powerful resource for the benefit of mankind especially in the area of food security and environmental sustainability. Soil characterization provides the information for our understanding of the physical, chemical, mineralogical and microbiological properties of the soils we depend on to grow crops, sustain forests and grasslands as well as support homes and society structures (Ogunkunle, 2005). Soil classification, on the other hand, helps to organize our knowledge, facilitates the transfer of experience and technology from one place to another and helps to compare soil properties. According to Eswaram (1977), some different uses of soil characterization data include to aid in the correct classification of the soil and enable other scientists place the soils in their taxonomies or classification systems and to serve as a basis for more detailed evaluation of the soil as well as gather preliminary information on nutrient, physical or other limitations needed to produce a capability class. A soil characterization study, therefore, is a major building block for understanding the soil, classifying it and getting the best understanding of the environment (Esu, 2005).

Owing to the fact that Dingyadi district is an agrarian community outskirt of Sokoto town and not much study has been done on the soils of the area, characterization and classification will help reveal information that could be useful in the management and use of the soils on a sustainable manner. The objective of this research therefore, is to characterize and classify the soils of Dingyadi District.

\section{MATERIALS AND METHODS Study Area}

The study site (500 hectares) is in Dingyadi District of Bodinga Local Government Area of Sokoto State, about 15 kilometers away from Sokoto town the administrative 
headquarters of the State $\left(13^{0} 56^{1} \mathrm{~N}, 130^{0} 58^{1} \mathrm{E}\right)$. It has a typical Sudan Savanna vegetation type. The area is intensively cultivated to array of crops such as onion, tomato, cowpea and millet. The length of growing period is 90-150 days (Ojanuga, 2006). The climate of Sokoto State is wet and dry, generally hot semi-arid tropics in Coppen classification of AW type (Sombroek and Zonneveld, 1971). It is characterized by long dry season from October through May/June and a short but intensive wet season from May/June through September with a mean annual rainfall slightly below $750 \mathrm{~mm}$. The rainfall pattern shows a marked seasonal variation with a single peak reaching maximum in August (Kowal and Knabe, 1972). The mean annual rainfall decreases gradually from the south to northern parts of the state. The rainy season is then followed by a short dry spell which could last for two to three months known as Harmattan. A period of cold, dry and dusty weather normally precedes the fairly long dry season.This dry season results from a dry and hot air mass blowing from north -east through the Sahara desert (FAO, 1969). The temperature fluctuates within a range of $16{ }^{\circ} \mathrm{C}$ during cold nights to over $40{ }^{\circ} \mathrm{C}$ during the hot days. The relative humidity during dry season is about $15-20 \%$ and reaches up to $70-75 \%$ during the rainy season. Most of the arable land consists of well drained upland with flat or slightly undulating topography which supports one growing season under rainfall conditions (Singh and Babaji, 1989).

\section{Field study}

A semi-detailed soil survey was conducted in Dingyadi area at a scale of 1:25,000 following the procedures described in Wilding and Dress (1983), using ranging poles, pegs and GPS instruments. Transects at 100 meters intervals were constructed at right angles $\left(90^{\circ}\right)$ to the either side of the baseline. This was followed by auger borings to examine and describe the soils consistently at 100 meters interval along each traverse. Observations relating to morphological properties of the soils, physiographic position, topography, colour, were used to establish the soil boundaries. Two modal profile pits were excavated in each identified soil mapping unit, the second pit in each unit serving as duplicate. The soil profiles were described according to FAO (2006) manual while the collection of bulked samples was made from each horizon for laboratory analysis. Samples for bulk density were taken with core samplers ( $5 \mathrm{~cm}$ diameter) from the various horizons. An infiltration test using double ring infiltrometer (Bouwer, 1986) was carried out beside pedons that are representative of the different soil units.

The entire mapped area was resolved into three soil mapping units namely TLL 1, TUP 2 and TUP 3 . Based on the data obtained from the soil survey, the soils at Dingyadi District were subsequently characterized and classified.

\section{Laboratory Methods}

The samples were air-dried, gently crushed using a wooden mortar and pestle and then sieved through a $2 \mathrm{~mm}$ mesh. The sieved samples were stored for chemical and physical analyses. Bulk density was determined by the core sampler method described by Blake and Hartge (1986). Particle size distribution was determined by the hydrometer method (Gee and Bauder, 1986) Particle density was determined by the use of Pycnometer bottle method (Blake, 1965). Total porosity was calculated from particle and bulk densities using the relationship $P=100(1-B d / P d)$, where $P=$ porosity, $\mathrm{Bd}=$ Bulk density, $\mathrm{Pd}=$ Particle density and 100 and 1 are constants. Soil pH (1:1) in $\mathrm{H}_{2} \mathrm{O}$ and $\mathrm{CaCl}_{2}$ were determined using glass electrode $\mathrm{pH}$ meter (Bates, 1954). Organic carbon content of the soils was determined by the modified Walkley-Black method as described by Nelson and Summers (1982). Total nitrogen was determined by the Macro-Kjeldahl digestion and distillation procedures as described by Bremer (1965). Available P was determined by Bray No. 1 Method (Bray and Kurtz, 1954). Exchangeable bases (calcium, magnesium, potassium and sodium) in the soil were determined using the ammonium acetate extract from the CEC determination. Sodium and $K$ were determined using flame photometer and $\mathrm{Ca}$ and $\mathrm{Mg}$ were determined using atomic absorption spectrometer while the percentage base saturation of the soils was calculated using the relationship below:

$$
\mathrm{BS}(\%)=\frac{\text { Exchangeable bases }}{\text { Cation Exchange Capacity }} \times 100
$$

\section{RESULTS AND DISCUSSION}

The morphological, physical, chemical and exchangeable properties of the soils are presented in Tables 1, 2, 3 and 4 respectively.

\section{Morphological Characteristics}

Summary of the morphological properties of the soils is presented on Table 1. In soil unit TLL1, the soils were dark reddish brown (5YR 2/3) at the surface and 
change to yellow (10YR 4/4) at the subsurface with yellowish red colour mottles (5 YR 4/6) to olive brown colour mottles (2.5 YR 3/6) in the subsurface horizons. This feature is indicative of the poor drainage status of the soils. The soils were generally deep and imperfectly drained. Texturally, the soils were loamy sand in the surface changing to sandy clay loam in the subsurface horizons. The structure of the soils was generally weak subangular blocky in the surface and changes to angular blocky in the subsurface.

Table 1: Morphological Properties of the Soils of Dingyadi District

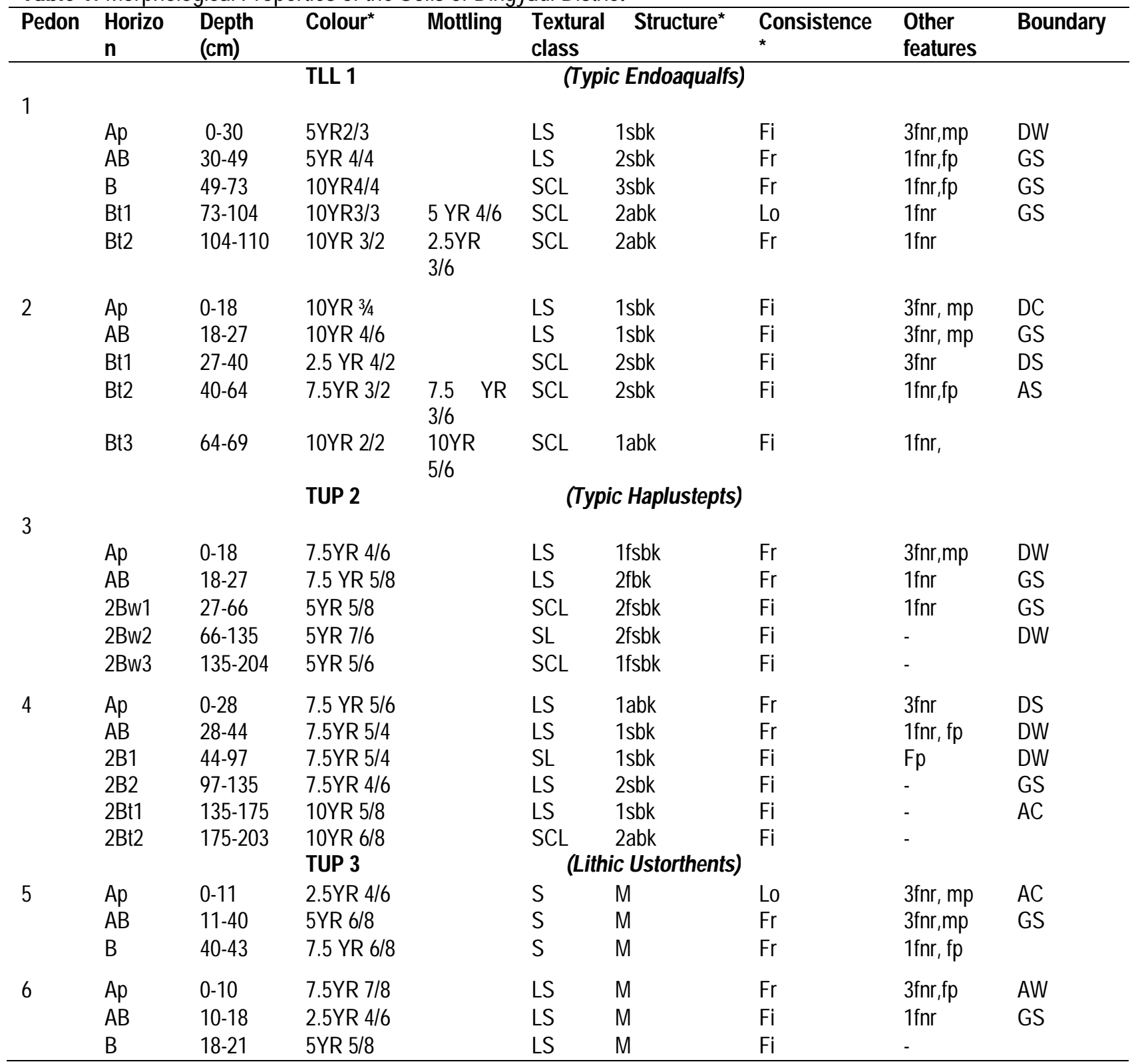

*Determined at wet condition, Note: symbols or codes according to FAO, 2006

Structure: $0=$ structureless, $1=$ weak, $2=$ moderate, $3=$ strong, $s g=$ single grain, csbk = coarse subangular blocky, fsbk= fine,

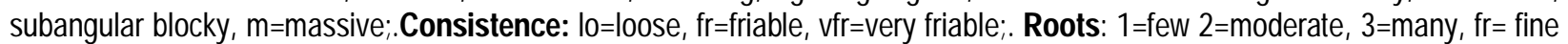
roots, $\mathrm{co}=$ coarse, $\mathrm{mp}=$ many pores, $\mathrm{fp}=$ few pores;. Boundary: $\mathbf{A}=$ abrupt, $\mathbf{C}=\mathrm{clear}, \mathbf{G}=$ gradual, $\mathbf{S}=$ =smooth, $\mathbf{W}=$ wavy

In soil unit TUP2, the surface colour of the soils was strong brown (7.5 YR 4/6) at the surface, changing to yellowish red (5YR 5/8) at the subsurface. The soils were well drained with deep rooting zone. The soils have angular blocky structure at the surface and changes to subangular blocky structure at the 
subsurface. The texture varies from loamy sand on the surface to sandy clay loam at the subsoil.

The soils in TUP 3 were brown in colour (2.5YR 4/6) in the surface and changed to reddish yellow (7.5 YR 6/8) at a depth of $40 \mathrm{~cm}$. An impermeable layer is reached at a depth of less than $50 \mathrm{~cm}$. The soils were generally gravelly sand in texture and were structurally massive.

Physical Characteristics

Generally, the soils of the study area have high sand content at surface except in TLL1 (Table 2).

Table 2: Physical Characteristic of the Soils of Dingyadi District

\begin{tabular}{|c|c|c|c|c|c|c|c|c|c|c|}
\hline Pedon & Horizon & Depth (cm) & $\begin{array}{l}\text { Sand } \\
\text { (\%) }\end{array}$ & $\begin{array}{l}\text { Silt } \\
\text { (\%) }\end{array}$ & $\begin{array}{l}\text { Clay } \\
\text { (\%) }\end{array}$ & $\begin{array}{l}\text { Silt/clay } \\
\text { Ratio }\end{array}$ & $\begin{array}{l}\text { Textural } \\
\text { class }\end{array}$ & $\begin{array}{l}\text { Bulk } \\
\text { density } \\
\left(\mathrm{mgkg}^{-1}\right)\end{array}$ & $\begin{array}{l}\text { Particle } \\
\text { Density } \\
\text { (mgkg-1) }\end{array}$ & $\begin{array}{l}\text { Porosity } \\
\text { (\%) }\end{array}$ \\
\hline \multicolumn{11}{|c|}{ TLL1(Typic Endoaqualfs) } \\
\hline \multirow[t]{6}{*}{1} & Ap & $0-30$ & 74 & 9 & 17 & 0.49 & LS & 1.48 & 2.47 & 40 \\
\hline & $A B$ & $30-49$ & 74 & 10 & 17 & 0.57 & LS & 1.62 & 2.41 & 33 \\
\hline & $\mathrm{B}$ & $49-73$ & 71 & 8 & 21 & 0.39 & $\mathrm{SCL}$ & 1.60 & 2.41 & 34 \\
\hline & Bt1 & $73-104$ & 71 & 7 & 21 & 0.41 & $\mathrm{SCL}$ & 1.50 & 2.47 & 39 \\
\hline & Bt2 & $104-110$ & 71 & 8 & 21 & 0.36 & $\mathrm{SCL}$ & 1.70 & 2.54 & 33 \\
\hline & & W.Average & 72 & 9 & 20 & 0.44 & & 1.58 & 2.46 & 36 \\
\hline \multirow[t]{6}{*}{2} & Ap & $0-18$ & 82 & 13 & 8 & 2.19 & LS & 1.40 & 2.47 & 43 \\
\hline & $A B$ & $18-27$ & 86 & 9 & 6 & 0.46 & LS & 1.66 & 2.54 & 34 \\
\hline & Bt1 & $27-40$ & 66 & 9 & 25 & 0.36 & $\mathrm{SCL}$ & 1.80 & 2.47 & 27 \\
\hline & $\mathrm{Bt2}$ & $40-64$ & 68 & 8 & 24 & 0.35 & $\mathrm{SCL}$ & 1.86 & 2.47 & 25 \\
\hline & $\mathrm{Bt3}$ & $64-69$ & 69 & 9 & 22 & 0.39 & $\mathrm{SCL}$ & 1.68 & 2.54 & 34 \\
\hline & & W.Average & 74 & 9 & 17 & 0.75 & & 1.68 & 2.50 & 33 \\
\hline \multicolumn{11}{|c|}{ TUP2 (Typic Haplustepts) } \\
\hline \multirow[t]{6}{*}{3} & Ap & $0-18$ & 88 & 7 & 6 & 1.10 & & 1.51 & 2.47 & 39 \\
\hline & $A B$ & $18-27$ & 87 & 7 & 6 & 1.09 & LS & 1.57 & 2.54 & 38 \\
\hline & 2Bw1 & $27-66$ & 75 & 5 & 21 & 0.23 & $\mathrm{SCL}$ & 1.62 & 2.47 & 34 \\
\hline & 2Bw2 & $66-135$ & 76 & 5 & 19 & 0.26 & $\mathrm{SCL}$ & 1.56 & 2.47 & 37 \\
\hline & 2Bw3 & $135-204$ & 73 & 7 & 20 & 0.33 & $\mathrm{SCL}$ & 1.49 & 2.54 & 41 \\
\hline & & W.Average & 74 & 6 & 14 & 0.60 & & 1.55 & 2.50 & 38 \\
\hline \multirow[t]{7}{*}{4} & AP & $0-28$ & 82 & 7 & 5 & 1.27 & LS & 1.41 & 2.41 & 42 \\
\hline & $A B$ & $28-44$ & 87 & 7 & 9 & 0.18 & LS & 1.37 & 2.47 & 45 \\
\hline & 2B1 & $44-97$ & 76 & 9 & 16 & 0.54 & $\mathrm{SL}$ & 1.34 & 2.54 & 47 \\
\hline & $2 \mathrm{~B} 2$ & $97-135$ & 82 & 6 & 12 & 0.47 & LS & 1.44 & 2.47 & 42 \\
\hline & $2 \mathrm{Bt1}$ & $135-175$ & 74 & 7 & 19 & 0.34 & LS & 1.39 & 2.47 & 44 \\
\hline & $2 \mathrm{Bt} 2$ & $175-203$ & 73 & 7 & 20 & 0.37 & $\mathrm{SCL}$ & 1.50 & 2.41 & 38 \\
\hline & & W.Average & 79 & 7 & 13 & & & & & \\
\hline \multicolumn{11}{|c|}{ TUP3 (Lithic Ustorthents) } \\
\hline \multirow[t]{4}{*}{5} & Ap & $0-11$ & 86 & 9 & 6 & 1.46 & S & 1.51 & 2.54 & 41 \\
\hline & $A B$ & $11-40$ & 88 & 7 & 6 & 1.12 & G & 1.40 & 2.47 & 43 \\
\hline & $\mathrm{B}$ & $40-43$ & 89 & 9 & 6 & 1.53 & G & 1.41 & 2.41 & 41 \\
\hline & & W.Average & 88 & 8 & 6 & 1.37 & & 1.44 & 2.47 & 42 \\
\hline \multirow[t]{4}{*}{6} & Ap & $0-10$ & 85 & 8 & 6 & 1.25 & $S$ & 1.53 & 2.41 & 36 \\
\hline & $A B$ & $10-18$ & 88 & 7 & 5 & 1.12 & G & 1.54 & 2.47 & 38 \\
\hline & $\mathrm{B}$ & & 84 & 9 & 9 & 1.11 & G & 1.60 & 2.47 & 35 \\
\hline & & W.Average & 83 & 8 & 8 & 1.16 & & 1.56 & 2.45 & 36 \\
\hline
\end{tabular}

LS-=Loamy sand, SCL=Silt Clay loam, $\mathrm{S}=$ sand, $\mathrm{g}=$ gravel W.Average= Weighted average 
These soils are formed on aeolian sand cover (Sombroek and Zonneveld, 1971). The silt content of the soils was observed to slightly increase with increasing depth in almost all the profiles. Morbeg and Esu (1991) and Kparmwang (1993) in the studies of soils in the Savanna region of Northern Nigeria mentioned the influence of Harmattan dust in contributing silt to soil. The soils of the study area are found to contain appreciable amount of clay content except in TUP 3. The higher clay content often observed in the subsurface horizons of many soils may be attributed to illuviation and pedoturbation processes. The presence of textural $B(B t)$ in soil units TLL1 and TUP2 confirms this.

The silt/clay ratio ranged from 0.35 to $2.19,0.35$ to 1 . 27 and 1.11 to 1.46 for TLL1, TUP2 and TUP3 respectively. Van Wambeke (1962) reported that "old" parent materials usually have a silt/clay ratio below 0.15 while silt/clay ratios above 0.15 are indicative of "young" parent materials. Results of this study show that, all the soils have silt/clay ratio above 0.15 indicating that the soils are relatively young with high degree of weathering potential. Silt/clay ratios are relatively higher in the surface horizons and decrease with increase depth in the pedons. The decrease in silt/clay ratio with depth is an indication that subsoils horizons are more weathered than surface horizons. Yakubu (2006) reported similar results on the soils of Sokoto State.

The relative high bulk density values recorded in TLL 1 is attributed to compaction caused by grazing animals which is a common activity in the area. Plant performs best in bulk densities below $1.4 \mathrm{Mgm}^{-3}$ and $1.6 \mathrm{Mgm}^{-3}$ for clayey and sandy soils respectively (Donahue et al; 1990).

Root growth could also be inhibited due to high bulk density because of soil resistance to root perpetration, poor aeration, slow movement of nutrients and water and build up of toxic gases and root exudates (Tarawali et al; 2001; Brady and Weil, 2002; Odunze, 2006). Consequently, the bulk density values of TUP 2 and TUP 3 are favourable for crop production, while that of TLL1 may impair proper root penetration.

This present study reveals an appreciable increase in particle density with depth of soil horizons. Brady (1987) reported that particle density values increase with soil depth. Similar results were also reported by Idoga et al (2006) in soils of Samaru area, Nigeria.
Porosity values of TLL 1 soil ranges from 25 to $40 \%$ (35\% average) 34 to 47\% (41\% average) in TUP 2 and 35 to $43 \%$ (39\% average) in TUP 3. Maniyunda and Malgwi (2011) reported similar values in the soils of Zaria, Kaduna State. Fetter (1998), and Riue and Sposito (1991) recommended that soils having porosity of over 50 percent and 45-50 percent of volume are good agricultural soils. Soil porosity is lower in TLL1 when compared to TUP 2 and TUP3 soils, this could be attributed to the clayey nature of the soils.

The low infiltration rate recorded in TLL 1(Table 3) could be attributed to its relative higher clay content and high bulk density. TUP 2 and TUP 3 soil units have high infiltration rates which could be attributed to its sandy nature. In line with this, soil of TUP 2 TUP 3 may be agriculturally poor because both moisture and soil nutrient losses can be high.

Table 3: Infilteration Rates (cmh-1) of the Soils of an Agricultural Landscape in Dingyadi District

\begin{tabular}{llll}
\hline \multirow{3}{*}{ Hours(s) } & \multicolumn{3}{c}{ Soil } \\
\cline { 2 - 4 } & TLL 1 & TUP 2 & TUP 3 \\
\hline 1 & 48 & 71 & 65 \\
2 & 34 & 62 & 57 \\
3 & 23 & 54 & 43 \\
4 & 17 & 41 & 34 \\
5 & 14 & 32 & 21 \\
Mean & 27.2 & 52 & 44 \\
MEIR & 20 & 40 & 32 \\
\hline
\end{tabular}

MEIR=mean equilibrium infiltration rate

\section{Chemical Characteristics}

Results of the chemical characteristics of the soils of Dingyadi District are presented in Table 4. The average $\mathrm{pH}$ values of the soils are 7.8, 7.1 and 7.0 for TLL I, TUP 2 and TUP 3 respectively. The pH was observed to increase or decrease irregularly with increasing depth. Similar trends were observed and reported by Yakubu and Ojanuga (2011). According to Landon (1991), a pH range of 5.5 to 7.0 is the preferred range for most crops. The pH value of TLL 1 indicates a slight alkaline reaction. This might be due to irrigation activities going on in the area.

Organic matter is generally very low in the soils according to Landon (1991) ratings ( $>20 \%$ very high, $10-20 \%$ high, 4-10\% medium, 2-4 \% low and < $2 \%$ very low). The low organic matter content of the soils in Sokoto State has been attributed to factors such as continuous cultivation, frequent burning of farm 
residues commonly carried out by farmers in the area which tends to destroy much of the organic materials that could have been added to the soil (Yakubu 2001). Furthermore, Agbu and Ojanuga (1989) stated that low organic matter content in soils of Sokoto area could be due to rapid decomposition and mineralization of organic materials contributed by sparse vegetation in the hot semi arid climate as promoted by radiation.

Table 4: Chemical Properties of the Soils of Dingyadi District

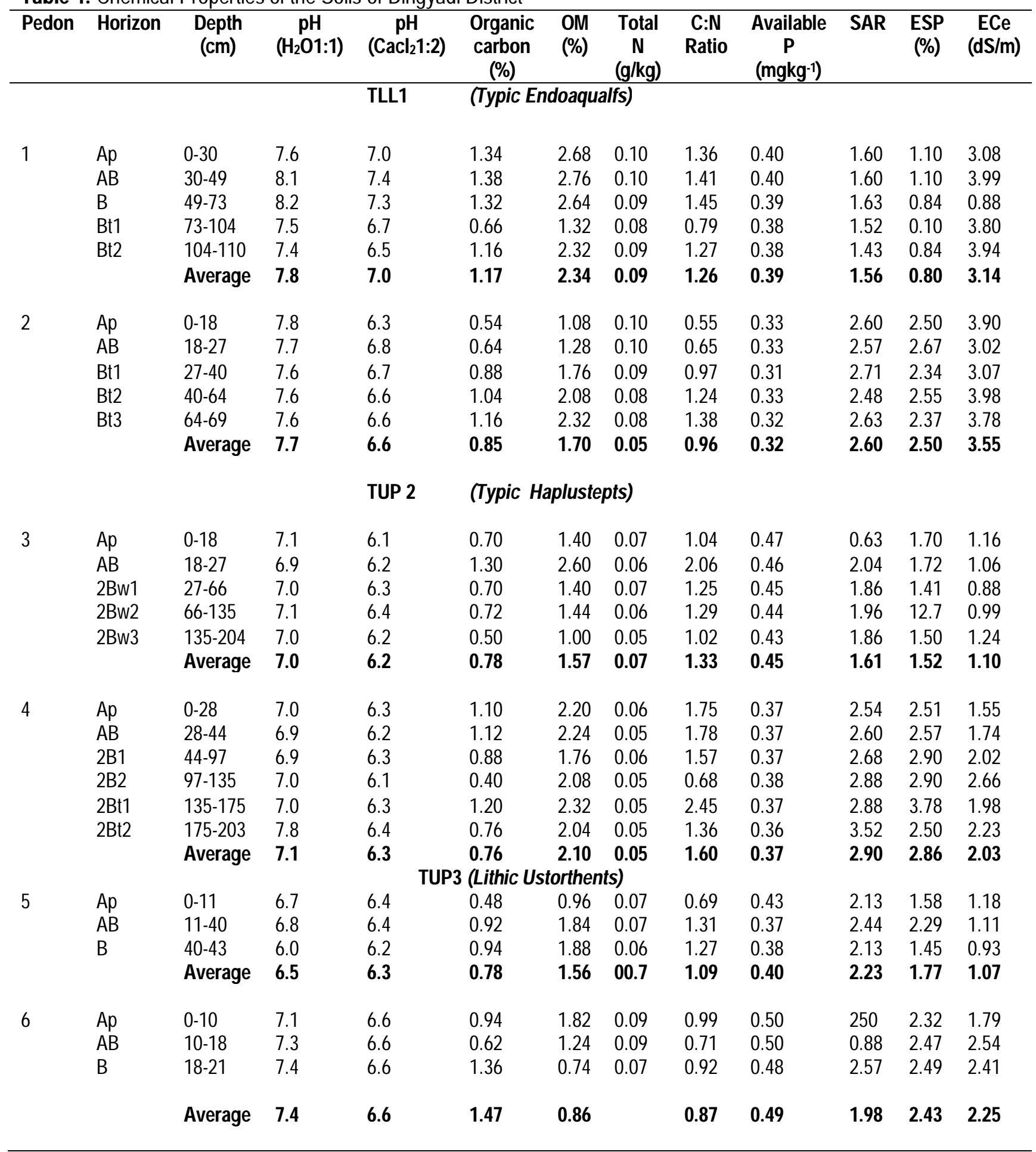


Total Nitrogen values ranged from 0.084 to $0.09 \mathrm{gkg}^{-1}$ $\left(0.09 \mathrm{gkg}^{-1}\right.$ average) in TLL $1,0.05$ to $0.06 \mathrm{gkg}^{-1}$ $\left(0.05 \mathrm{gkg}^{-1}\right.$ average) in TUP 2 and 00.7 to $0.09 \mathrm{gkg}^{-1}$ $\left(0.082 \mathrm{gkg}^{-1}\right.$ average) in TUP 3. Similar results of low $\mathrm{N}$ values were reported by Kparmwang (1996) in Bauchi State. The total nitrogen values of the soils in the area changed irregularly with depth which could be attributed to influence of continuous cultivation, a common practice in the area that is accompanied by nearly crop residue removal (Noma et al 2011).

Electrical Conductivity (EC) ranged from 1.88 to $3.30 \mathrm{dSm}^{-1}$ in TLL1 (3.3 dSm$)^{-1}$ average), 0.88 to $2.60 \mathrm{dSm}^{-1}$ in TUP $2\left(1.50 \mathrm{dSm}^{-1}\right.$ average) and 0.90 to $1.08 \mathrm{dSm}^{-1}\left(1.30 \mathrm{dSm}^{-1}\right.$ average) in TUP 3 . The average EC value of soil unit TLL 1 indicates salinity status in the soils. The mean values for TUP 2 and TUP 3 were generally low indicating the non-saline status of the soils according to the limits set by Schoeneberger et al (2002).

The values of exchangeable sodium percentage (ESP) in all the three soil units are generally below 15\% (Table 5), the critical limit for sodicity (Brady and Weil, 2002). The Sodium Adsorption Ratio (SAR) values are rated low, below the threshold value of 13 for sodic soils (Sanda et al 2007). Similar results were obtained by Yakubu et al., (2011) in soils in Sanyinna area of Sokoto State.

The exchangeable bases of the soils are generally low. Similar results were reported from Sokoto by Noma et al, (2004). Calcium and magnesium are the predominant basic cations in the soils. Similar observations have been made in the past for West African soils in general (Kowal and Knabe, 1972). It is also in tune with findings of Noma et al, (2004); Yakubu, (2006); and Yakubu et al, (2011). The mean values of $\mathrm{K}: \mathrm{Mg}$ of soil TLL 1, TUP 2 and TUP 3 are 1.2, 0.98 and 0.74 respectively. Cation ratios help in identifying soil structural problems. $\mathrm{Mg}$ problems are more frequent when the soil $\mathrm{K}: \mathrm{Mg}$ ratio exceeds 1.5:1. High $\mathrm{Mg}$ soils cause $\mathrm{K}$ deficiency in plants; and soils with high $\mathrm{Mg}$ tends to have poor structure. The mean values of Ca: $\mathrm{Mg}$ is 1.0, 0.80 and 2.6 for TLL 1, TUP 2 and TUP 3 respectively. Correct $\mathrm{Ca}$ : $\mathrm{Mg}$ ratio will improve soil structure, reduce leaching of other plant nutrients, reduce weed population and generally improve the balance of most soil nutrients.

Cation Exchange Capacity of the soils is generally low according to Esu (1991) rating of $<6$ low, 6-12 medium and $>12$ high. The low CEC of the soils could be attributed to the nature of clay minerals (kaolinite) (Opuwaribo and Odu 1978; Juo and Moorman, 1981; Hassan et al; 2011). Yakubu et al (2011) opined that organic matter content of soils which normally influences the CEC is generally low and therefore the CEC values may not be attributed to the amount of organic matter.

The effective cation exchange capacity (ECEC) of the soils is also low, an indication that the soils at their natural $\mathrm{pH}$ levels remain low in CEC indicating a low capacity of the soils to retain nutrients (Yakubu 2006).

Soil unit TLL 1 has base saturation of 35 to $68 \%$ (49\% average), 29 to $65 \%$ (41\% average) in soil unit TUP 2 and 38 to $45 \%$ (42\% average) in soil unit TUP 3. FAO (1999) reported that soils with base saturation of $>50 \%$ are regarded as fertile soils while soils with less than $50 \%$ were regarded as not fertile soils. Based on this therefore, the soils are generally not fertile.

\section{Soil Classification}

The soils have been classified according to the USDA Soil Taxonomy (Soil Survey Staff, 2010) and correlated with the World Reference Base (WRB) for soil resources (FAO, 1998). 
Table 5: Exchangeable Characteristics of the Soils of Dingyadi District

\begin{tabular}{|c|c|c|c|c|c|c|c|c|c|c|c|}
\hline & & & & Excha & eable b & & & & & & \\
\hline Pedon & Horizon & Depth & $\mathrm{Ca}$ & $\mathrm{Mg}$ & $\mathrm{Na}$ & $\mathrm{K}$ & CEC & ECEC & Ca:Mg & Base & $\mathrm{K}: \mathrm{Mg}$ \\
\hline & & & & & & Cmolk & & & & (\%) & \\
\hline & & & & TLL1 & Typic & Endoa & jalfs & & & & \\
\hline 1 & $A p$ & $0-30$ & 0.75 & 0.60 & 0.40 & 1.15 & 4.53 & 5.39 & 1.25 & 64 & 1.92 \\
\hline & $A B$ & $30-49$ & 0.75 & 0.60 & 0.40 & 1.08 & 4.16 & 5.22 & 1.25 & 68 & 1.80 \\
\hline & B & $49-73$ & 0.75 & 0.60 & 0.43 & 0.97 & 4.52 & 5.15 & 1.25 & 61 & 1.62 \\
\hline & Bt1 & 73-104 & 0.60 & 0.65 & 0.30 & 0.97 & 4.52 & 4.82 & 0.92 & 56 & 1.49 \\
\hline & Bt2 & 104-110 & 0.50 & 1.00 & 0.30 & 0.67 & 4.42 & 4.87 & 0.50 & 59 & 0.67 \\
\hline & & Average & 0.67 & 0.69 & 0.35 & 1.02 & 4.43 & 5.09 & 1.03 & & 1.50 \\
\hline 2 & Ap & $0-18$ & 0.65 & 0.60 & 0.22 & 0.54 & 4.92 & 5.31 & 1.08 & 41 & 0.90 \\
\hline & $A B$ & $18-27$ & 0.55 & 0.70 & 0.22 & 0.54 & 4.92 & 5.31 & 0.79 & 41 & 0.77 \\
\hline & 2Bw1 & $27-40$ & 0.55 & 0.55 & 0.22 & 0.54 & 4.86 & 5.26 & 1.00 & 38 & 0.98 \\
\hline & 2Bw2 & $40-64$ & 0.50 & 0.55 & 0.20 & 0.49 & 4.80 & 4.94 & 0.91 & 36 & 0.89 \\
\hline & 2Bw3 & $64-69$ & 0.50 & 0.50 & 0.21 & 0.49 & 4.80 & 4.98 & 1.00 & 35 & 0.98 \\
\hline & & Average & 0.55 & 0.68 & 0.21 & 0.52 & 4.86 & 5.16 & 1.00 & 49 & 0.90 \\
\hline & & & & & TUP2 & Typic & Haplustep & & & & \\
\hline 3 & Ap & 0-18 & 0.70 & 0.80 & 0.14 & 0.57 & 3.42 & 4.91 & 0.88 & 65 & 0.71 \\
\hline & $A B$ & $18-27$ & 0.60 & 0.65 & 0.17 & 0.28 & 3.48 & 5.07 & 0.92 & 49 & 0.43 \\
\hline & 2Bw1 & $27-66$ & 0.60 & 0.70 & 0.16 & 0.31 & 3.50 & 5.11 & 0.86 & 51 & 0.44 \\
\hline & 2Bw2 & 66-135 & 0.60 & 0.60 & 0.16 & 0.28 & 3.48 & 5.13 & 1.00 & 47 & 0.47 \\
\hline & 2Bw3 & $135-204$ & 0.50 & 0.70 & 0.16 & 0.76 & 3.44 & 4.93 & 0.71 & 62 & 1.09 \\
\hline & & Average & 0.60 & 0.69 & 0.16 & 0.44 & 3.50 & 5.03 & 0.87 & & 1.09 \\
\hline 4 & Ap & $0-28$ & 0.25 & 0.35 & 0.19 & 0.26 & 3.40 & 4.23 & 0.71 & 31 & 0.74 \\
\hline & $A B$ & $28-44$ & 0.25 & 0.35 & 0.17 & 0.23 & 3.40 & 3.87 & 0.71 & 29 & 0.66 \\
\hline & 2B1 & $44-97$ & 0.25 & 0.30 & 0.17 & 0.26 & 3.40 & 4.05 & 0.83 & 29 & 0.87 \\
\hline & 2B2 & 97-135 & 0.25 & 0.30 & 0.19 & 0.26 & 3.32 & 4.08 & 0.83 & 31 & 0.87 \\
\hline & 2Bt1 & $135-175$ & 0.25 & 0.30 & 0.19 & 0.28 & 3.28 & 4.10 & 0.82 & 31 & 0.93 \\
\hline & $2 \mathrm{Bt} 2$ & 175-203 & 0.15 & 0.35 & 0.22 & 0.51 & 3.92 & 4.53 & 0.43 & 30 & 0.98 \\
\hline & & Average & 0.23 & 0.32 & 4.13 & 0.72 & & & & & \\
\hline & & & & & TUP 3 & Typic & storthents & & & 41 & \\
\hline 5 & Ap & $0-11$ & 0.65 & 0.20 & 0.16 & 0.26 & 3.34 & 4.48 & 3.25 & 38 & 1.30 \\
\hline & $A B$ & $11-40$ & 0.65 & 0.25 & 0.19 & 0.26 & 3.32 & 4.83 & 2.60 & 41 & 1.04 \\
\hline & B & $40-43$ & 0.65 & 0.15 & 0.16 & 0.28 & 3.22 & 4.65 & 4.33 & 39 & 0.43 \\
\hline & & Average & 0.65 & 0.20 & 0.17 & 0.27 & 3.30 & 4.65 & 3.39 & & 0.92 \\
\hline 6 & Ap & $0-10$ & 0.82 & 0.50 & 0.22 & 0.24 & 3.93 & 5.58 & 1.64 & 45 & 0.48 \\
\hline & $A B$ & $10-18$ & 0.85 & 0.50 & 0.22 & 0.26 & 4.10 & 5.58 & 1.64 & 45 & 0.52 \\
\hline & B & Average & 0.75 & 0.40 & 2.14 & 0.26 & 4.27 & 5.05 & 1.88 & 42 & 0.65 \\
\hline
\end{tabular}

Table 6: Correlation Between USDA Soil Taxonomy and World Reference Base (WRB) for Soil Resources

\begin{tabular}{llll}
\hline Soils unit & \multicolumn{1}{c}{ Local name } & USDA Soil Taxonomy & WRB \\
\hline TLLI & Tulluwa series & Typic Endoaqualfs & Haplic Luvisols \\
TUP2 & Runjin Abdu series & Typic Haplustepts & Argic Lixisols \\
TUP3 & Saidawa series & Lithic Ustorthents & Ruptic Cambisols \\
\hline
\end{tabular}


Soil Classification according to USDA Soil Taxonomy and World Reference Base (WRB) for Soil Resources

Soil unit TLLI is classified as Alfisol at order level because of the presence of an argillic horizon. It is Aqualfs at the suborder level because of the redoximorphic features in all layers (evidenced by mottle colours in the subsurface horizons). It is classified as Endoaqualfs at the great group level because it has saturation layer below $50 \mathrm{~cm}$ (Epiaqualfs have episaturation). At the sub group level it is further classified as Typic Endoaqualfs because it does not fit into the other aqualfs (Natric vermaqualfs). It was further classified as Tulluwa series because it was identified near Tulluwa settlement

Soil unit TUP2 is classified as Inceptisols at order level because it has cambic horizon (an altered horizon in which the parent material have been changed into soil by formation of structure - clay formation). At the suborder level they classify as Ustepts because the soils have Ustic moisture regime. They further classify as Haplustepts. At sub group level, they classify as Typic Haplustepts because they do not fit into other Haplustepts. They further locally named tentatively as classified as Runjin Abdu series after Runjin Abdu settlement

Soils of map unit TUP3 classify as Entisols at the order level because the soils show no evidence of horizon development. At the suborder level they classify as Orthents. At the great group level, they classify as Ustorthents because of the soils Ustic moisture regime. At the subgroup level they classify as Lithic Ustorthents because of the lithic contact (ironstone crust) within $50 \mathrm{~cm}$. They further classify locally as Saidawa series after Saidawa settlement

\section{Classification According to the World Reference Base (WRB)}

TLLI is classified as Luvisols at the reference soil groups (RSGs) for having an argic horizon overlain by loamy sand. At the lower level, TLLI is classified as Haplic Luvisols for having a texture of loamy sand.

TUP2 is classified as Lixisols for having an argic horizon within two hundred centimeter of the soil surface overlain by loamy sand. At the lower level it is classified as Argic Lixisols for having subsurface horizon with distinct higher clay content then the overlying horizon. TUP3 is classified as Cambisols because of a cambic horizon starting within fifty centimeter of the soil surface. At the lower level they are classified as Ruptic Cambisols for having a lithological discontinuity within one hundred centimeter of the soil surface.

\section{Management implications of the soil properties}

The low fertility status of the soils of Dingyadi District can be brought to better use for agriculture by increasing the organic matter level through incorporation of organic residues such as farmyard manure, plant residues, and household refuse. For sustainable crop production, there is need for guided inorganic fertilizer use and improved management practices in the area that will effectively minimize erosion and enhance and maintain soil quality and productivity.

Soil Unit TLL1 has drainage problem as it is often inundated during the rainy season. There is need to monitor the water table and develop good irrigation schedule in order to allow the growth of water loving crops and vegetables. On the basis of landform and other soil properties, the soils on map units TUP 2 and TUP 3 could best be used for arable crops such as millet, sorghum and cowpea.

\section{CONCLUSION}

Characterization of soils of Dingyadi District reveal that the soils were predominantly of colluvio-alluvial origin and low in inherent fertility as evidenced by low organic matter, base saturation and low CEC. The soils are neutral to slightly alkaline. The study has brought out clearly relevant soil information that can guide decision on the use and management of soils of the area on a sustainable basis.

\section{REFERENCES}

Agbu, P.A. and A. G. Ojanuga. (1989). Properties and classification of soils of Dange area of Sokoto State, Nigeria. Samaru Journal of Agricultural Research, 6:37-47

Blake G.R., and Hartge, K.H. (1986). Bulk density. In methods of Soil Analysis. Klute A. (Ed). Part 1. $2^{\text {nd }}$ ed. Agron. 9. ASA and SSA, Madison, W1. P.363375.

Bates, R.C. (1954). Electrometric pH determination, John Wiley and sons Inc. New York.

Bremer, M.J. (1965). Total Nitrogen in: C.A Black (Ed). Methods of soil Analyses. 1149-1179. 
Brady, N.C. and R. R. Weil. (2002). The Nature and Properties of Soils 13th edition, Pearson Prentice Hall inc. Pte. Ltd. Indian Branch, Delhi, India. pp.976.

Brady, N.C. (1987). The nature and properties of Soils, $8^{\text {th }}$ edition, Macmillan, New York.

Donahue, R.L, Raymond, M.W. and Schick Line, J.C. (1990). Soils: An introduction to soils and plant growth. Prentice hall of India. 667pp

Eswaran, H. (1977). Soil Analysis for Soil Surveys. In: Soil Resource Inventories. A proceedings of a workshop held at Cornell University, Ithaca, USA, pp 315-324

Esu, I.E. (1991). Detailed Soil Survey of NIHORT Farm at Bunkure, Kano State, Nigeria. Institute for Agricultural Research, Ahmadu Bello University, Zaria.

Esu, I.E (2005). Soil characterization and mapping for food security. A Keynote Address at the 29th annual conf. of SSSN held at University of Nigeria, Abeokuta, from 6th to 10th Dec. 2004.

Fasina, A.S., Omolayo, F.A., Ajayi, SO., and Falodun, A.A. (2007). Influence of Land Use on Soil Properties in Three Mapping Units in Southwestern Nigeria-Implications for Sustainable Soil Management. In Uyovbisere, E.O, Raji, B.A, Yusuf, A.A, Ogunwale, J.O, Aliyu, L. and Ojeniyi, S.O (Eds). Soil and water management for poverty alleviation and sustainable Environment Proceedings of the 31 st annual conf. of SSSN/ABU Zaria Nig. Nov. 13th to 17th, 2006. FAO. (1969). Soil and Water Resources Survey of the Sokoto Valley, Nigeria. Final Report, Vol. 5. FAO/SF, Rome

FAO (1999). World Reference Base for Soil Resources. World Soil Resources Rep. vol. 84. Food and Agricultural Organisation of the UN, Rome, Italy, 161p. FAO (2006). Guidelines for Soil Description. Fourth Edition. 109pp Fetter, C.W (1998). Applied Hydrogeology, Macmillan publishing co. New York. Gee, G.W. and Bauder, J.W. (1986). Particle-size analysis. In methods of soil analysis. A Klute (Ed). Part 1. 2nd ed. Agron. ASA and SSSA, Madison WI.P383.

Hassan, A.M., Raji, B.A., Malgwi, W.B., and Agbenin, J.O. (2011). The Basaltic soils of Plateau State, Nigeria. Properties, classification and management practices. In M.K.A., Adebayo, A.J. Odofin, A.O. Osunde, A. Bala and S.O. Ojeniyi (Eds). Soil Resources Management, Global Climate Change and Food Security. Proceedings of the 35th annual conferences of SSSN/Minna, Nigeria March, 7th to11th, 2011.

Idoga, S., Ibanga, I.J. and Malgwi, W.B. (2006). Variation in Soil morphological and physical properties and their management implications on a toposequence in Samaru area, Nigeria. pp. 1925. In Proceedings of the 31st Annual Conference of Soil Science Society of Nigeria. Ahmadu Bello University, Zaria, Nigeria. November 13-17.

Juo, A.S.R. and Moorman, F.R. (1981). Characteristics of two soil toposequence in southeastern Nigeria and their relation to potential land use. Nigeria Journal of Soil Science. 1: 47-61.

Kowal, D. and Knabe D.J (1972). An Agroclimatological Atlas of the Northern State of Nigeria. Ahmadu Bello Univ. press, Zaria, Nigeria.

Kparmwang, T. (1993). Characterization and classification of Basaltic soils in the Northern Guinea savanna zone of Nigeria. Unpublished PhD thesis, Dept. of Soil science, ABU, Zaria, pp. 176.

Kparmwang, T. (1996). Inherent fertility status of upland and Fadama soils in Bauchi state, Nigeria. Noma, 12:1-7.

Landon, J.R. (1991). Booker Tropical Soil Manual. Longman Scientific and Technical Essex, UK. pp. 474.

Lekwa, M.U., Anene, B.O. and Lekwa, G. (2004). Chemical and Morphological Soil Characteristics in Drainage Toposequence in Southeastern Nigeria. In Ojeniyi, S.O., Ano, A.O., Awasalam, D.O. and Chukwu, G.O. (Ed) Land Degradation, Agricultural Productivity and rural poverty, environmental implications proceedings of the $28^{\text {th }}$ Annual Conference of the Soil Science Society of Nigeria, held at National Root Crops Research Institute, Umudike, Abia State. Nov. 2003, $4^{\text {th }}-7^{\text {th }}$ pp. 316-322

Morbeg, J.P and Esu, I.E. (1991). Characteristics and composition of Nigeria savanna soils, Geoderma, 48:113-129

Maniyunda, L.M. and Malgwi, W.B. (2011). PhysicoChemical properties and management strategies for soils along river Galma, Zaria, Nigeria. In: Adebayo, M.K.A., Odofin, A.J., Osunde, A.O, Bala, A. And Oyeniyi, S.O. (Eds). Soil Resources Management global climate change and food security. Proceedings of the 35th annual conf. of SSSN/Minna, Niger State, March 7th to 11th, 2011.

Mbagwu, J.S.C. (1981). Effects of land use on the hydrological properties of a southeastern Nigeria 
soils. Beitrage Ed trop. Landwirtsch veterinam, 25: 375-382

Nelson, D.W. and Summers, E. (1982). Total C, organic matter. In page, A.L., Miller, R.H. and Keeny, D.R. (Eds) method of soil analysis. Part 2. chemical and microbiological properties, 3rd ed.

Noma, S.S., Ojanuga, A.G., Ibrahim, S.A. and lliya, M.A. (2004). Detailed soil survey of the SokotoRima flood plains at Sokoto, Nigeria. In Salako, F.K, Adetunji, M.T, Ojanuga, A.G, Arowolo T.A. and Ojeniyi, S.O. (Eds). Managing Soil resources for food security and sustainable environment. Proceedings of the 29 th annual conf. of SSSN/University of Agriculture, Abeokuta, Nigeria Dec. 6-10, 2004.

Noma, S.S., Tanko, I.I, Yakubu, M. Dikko, A.U., Abdullahi A.A. and Audu, M. (2011). Variability in the physico-chemical properties of the soils of Dundaye District, Sokoto State, Nigeria. In Hassan, W.A. Kyiogom, U.B. Tukur, H.M. Ipinjolu, J.K. Maigandi, S.A. Singh, A., Ibrahim, N.D., Dikko, A.U., Bashir, Y.A. and Muhammad, N. (Eds). Mobilizing agricultural research towards attaining food security and Industrial growth in Nigeria. Proceedings of the 45th annual conferences of the Agricultural Society of Nigeria held at the Faculty of Agriculture, Usmanu Danfodiyo University Sokoto, Nigeria, $24^{\text {th }}$ to $28^{\text {th }}$ Oct.

Ojanuga, A.G. (2006). Agro ecological zones of Nigeria Manual. National Special programme for food security and FAO. Pp 124.

Odunze, A. C. (2006) Soil properties and management strategies for some sub-humid savanna zone Alfisols in Kaduna State, Nigeria. Samaru Journal of Agricultural Research 22: 3-14.

Ogunkunle A.O.; (2005). Soil Survey and Sustainable Land Management. Invited paper at the $29^{n}$ annual conf. of SSSN held at University of Nigeria, Abeokuta, from 6th to 10th Dec. 2004.

Opuwaribo, E. and Odu, C.T.I. (1978). Ammonium Fixation in Nigeria soils: 5 types of clay minerals and relationships with ammonium fixation. Soils Science Society, 25:283-293. Rieu, S. and Sposito, T. (1991). Fractal Fragmentation, soil porosity and soil water properties. 1. Theory. Soil Science. Society of American Journal, 55:12311238.

Soil Survey Staff, (2010). Keys to Soil Taxonomy. 11 Edition. USDA/NRCS, Washington, DC. 338pp. Sombroek, W.G. and Zonneveld, I.S. (1971).
Ancient Dunes Fields and Fluviatile Deposits in the Rima. Sokoto River Basin Soil Survey Paper No.5, Netherland Soil Survey Institute, Wageningen, pp109.

Schoeneberger, P.J., Wysocki, D.A., Benham, E.C. and Broderson, W.D. (Eds). (2002). Field book for describing and sampling soils, version 2.0 Nat. Soil survey center. NRCS, USDA, Lincolns, NE.

Sanda, A.R., Ogunwale, J.O., Oluwasemire, K.O. and Raji, B.A. (2007). Effects of Drainage water recycles and irrigation scheduling on soil properties and yield of tomato under a high water table in Northern Nigeria. In Uyovbisere, E.O., Raji, B.A., Yusuf, A.A, Ogunwale, J.O, Aliyu, L. and Ojeniyi, S.O (Eds). Soil and water management for poverty alleviation and sustainable environment. Proceeding of the $31_{\text {st }}$ annual conference of SSSN/ABU, Zaria, Nigeria Nov. 11th to 17 th, 2006

Singh, B.R. and Babaji, G.A. (1989). Characteristics of the Soils in Dundaye District: the Fadama Soils of the University Dryland Farm. Nigeria Journal of Basic and Applied Science, 3(1): 7-16.

Wilding, L.P. and Dress, L.R. (1983). Spatial variability and Pedology. In: wilding, L.P., Smack, N.E. and

Hall, G.F. (Eds) Pedogenesis and Soil Taxonomy. 1. Concepts and interactions. New York. Elsevier. pp. 83-1.

Yakubu, M. (2006). Genesis and classification of soils over different geological formations and surfaces in the Sokoto plains Nigeria. PhD Thesis. Soil science and Agricultural Engineering Department, Usmanu Danfodiyo University Sokoto (Unpublished).

Yakubu M. (2001). Survey, Classification and Genesis of soils of Kalambaina area, Sokoto State, Nigeria. M.Sc. Thesis, Department of Soil Science and Agricultural Engineering, University of Agriculture, Abeokuta (Unpublished)

Yakubu, M., Baraya, S. and Noma, S.S. (2011). Assessment of soil and water quality along river Kadarko in Sanyinna District, Sokoto State. In Hassan, W.A. Kyiogom, U.B. Tukur, H.M. Ipinjolu, J.K. Maigandi, S.A. Singh, A., Ibrahim, N.D., Dikko, A.U., Bashir, Y.A. and Muhammad, N. (Eds). Mobilizing agricultural research towards attaining food security and Industrial growth in Nigeria. Proceedings of the 45th annual conferences of the ASN held at the Faculty of Agriculture, UDUS, Nigeria, 24th to 28th Oct. 